\title{
Apoptosis Induced by Ziziphora tenuior Essential Oil in Human Colorectal Cancer Cells
}

\author{
Mohammadreza Azimi, ${ }^{1}$ Jalil Mehrzad, ${ }^{2}$ Armita Ahmadi, ${ }^{3}$ Elnaz Ahmadi, \\ and Ali Ghorbani Ranjbary (D) $^{2}$ \\ ${ }^{1}$ Department of Biochemistry, Medical Faculty, Saveh Branch, Islamic Azad University, Saveh, Iran \\ ${ }^{2}$ Department of Microbiology and Immunology, Faculty of Veterinary Medicine, University of Tehran, Tehran, Iran \\ ${ }^{3}$ Research Institute of Agricultural, Ferdowsi University of Mashhad, Mashhad, Iran \\ ${ }^{4}$ Faculty of Chemistry, Islamic Azad University of Tehran, Iran
}

Correspondence should be addressed to Ali Ghorbani Ranjbary; ali.ghorbaniranjbary@mail.um.ac.ir

Received 18 February 2021; Revised 6 June 2021; Accepted 13 July 2021; Published 23 July 2021

Academic Editor: Kazim Husain

Copyright ( 2021 Mohammadreza Azimi et al. This is an open access article distributed under the Creative Commons Attribution License, which permits unrestricted use, distribution, and reproduction in any medium, provided the original work is properly cited.

\begin{abstract}
Ziziphora (Cacotti in Persian) belongs to the Lamiaceae family (mint group) and is vastly found in Iran and Asia. This traditional medicinal plant is normally used as analgesic and for treatment of particular gastrointestinal diseases. Since colorectal cancer is one of the most common causes of death in the world and the second leading cause of cancer death among adults, there is a pressing need to inhibit this malignancy by using methods with minimal side effects. One of these methods is the use of natural resources such as medical plants. This study is aimed at investigating the expression of apoptosis-related genes in the adjacent culture of colorectal cancer epithelial cells (HT-29) with Ziziphora essential oil (ZEO). The essential oil was extracted from Ziziphora leaves, and its compounds were determined and then added to the HT-29 culture medium at different concentrations. After 24 hours, the HT-29 cells were harvested from the medium and cytotoxicity was analyzed by MTT assay. After MTT assay and determination of the percentage of apoptosis by flow cytometry, RNA extraction was performed and the expression levels of Bax, Bcl-2, caspase 3 (C3), and caspase 9 (C9) were analyzed using newly designed primers by reverse transcription (RT) qPCR method and GeniX6 software. Also, specific antibodies were used for western blot analyses of those molecules. GC analysis revealed 42 different compounds in the ZEO, including pulegone (26.65\%), menthone (5.74\%), thymol (5.51\%), and menthol (1.02\%). MTT assay showed that the concentration of $200 \mu \mathrm{g} / \mathrm{ml}$ of ZEO had the highest HT-29 cell death during 24 hours. After incubation with the concentration of $50 \mu \mathrm{g} / \mathrm{ml}$ of ZEO for 24 and 48 hours, caspase 3 and 9 gene expressions in the treated group increased compared to those in the control group $(P<0.001)$, while the Bcl-2 expression decreased. The results showed that having anticancer compounds, ZEO can increase C3 and C9 and decrease Bcl-2 expressions, causing apoptosis in HT-29 cells in vitro. This can lead to the use of ZEO as a factor for colorectal cancer treatment.
\end{abstract}

\section{Introduction}

Cancer has always been one of the most fundamental issues of human health. Despite a large number of researches and developments in the past decade, cancer remains one of the most important causes of death globally. According to the most recent statistics, cancer is the second leading cause of death in the world after cardiovascular disease [1-3]. Recent studies have shown that colorectal cancer (CRC) is the sec- ond most common cancer in women after breast cancer and the most common cancer in men after lung cancer [4, 5]. CRC is one of the most common malignancies that cause many deaths annually and the second most deadly cancer worldwide with about 881,000 deaths in 2018 [6]. Nowadays, different methods including surgery, chemotherapy, and radiotherapy are used to treat cancer, but one of the side effects of these methods is the loss of healthy cells, which has led researchers to move towards new methods of 
treatment by reducing side effects $[6,7]$. Using medical plants and their extracts as a treatment for cancer has attracted attention, and a lot of research on this area has recently been conducted. HT-29, adenocarcinoma cell, is one of the most widely used epithelial-derived cell lines to mimic the behavior of epithelial cell cancer and CRC therapy in laboratory and clinics $[8,9]$.

Ziziphora is a traditional medicinal plant in the family Lamiaceae. This plant is a subshrub, its height is between 20 and $50 \mathrm{~cm}$, and the leaves are small, opposite, almost lanceolate, and without petioles. It also has small and complete flowers in white, pink, and purple. Its medicinal properties can be used in the treatment of digestive disorders such as diarrhea and colic [10]. Besides, Ziziphora has antibacterial [11, 12], antioxidant [13], and intestinal disinfectant [12] effects. Ziziphora extract has also been shown to increase the activity of caspases 3 and 9 through the internal pathway of apoptosis, causing apoptosis and necrosis even in larvae of hydatid cyst $[14,15]$. Further, the alcoholic extract of the aerial part of Ziziphora, due to its compounds such as menthol, can cause cytotoxicity in various cancerous cells (e.g., HT-29 and T-47D cell lines).

The most important Ziziphora phytochemical compounds are thus the anticancer ones including pulegone, menthol, and menthone. In recent studies, the anticancer effects of these compounds have been observed. Its mechanism is through the effect on various messaging pathways such as apoptosis, cell viability, and proliferation [14-16]. Ziziphora has effective substances such as cineole, piperitone, menthone, pulegone, isomenthol, and curcumin [11-16].

Therefore, according to the results of previous studies $[14,15]$ and the mechanism of the unknown effect of Ziziphora essential oil (ZEO) on HT-29 cells in the present study, our current study is aimed at investigating the expression of apoptotic-related genes in the adjacent culture of colorectal epithelial cancerous cells with ZEO.

\section{Materials and Methods}

2.1. Ziziphora Essential Oil (ZEO) Preparation Method. The leaves and branches of Ziziphora tenuior were dried in shade and ground by a grinding machine. Then, the essential oil was extracted by water distillation in a Clevenger apparatus (type apparatus 1928) for 3 hours. The ratio of essential oil to the dry weight of the plant was $5 \%$. The harvested ZEO was then stored in dark glass for subsequent use.

First, ZEO was extracted and then its compounds were identified by a GC-MS (HP-6840/5973) spectrometer in the central laboratory of Ferdowsi University of Mashhad. The components were identified by comparing their mass spectrum with the existing standard spectrum.

The rest of the present study was performed in the central laboratory of Faculty of Veterinary Medicine, University of Tehran, and the biotechnology department of Ferdowsi University of Mashhad in 2019 with a code of ethics IR.MUMS.REC.1398.42456. The HT-29 cell line was purchased from the biotechnology department (cell bank). Cells were cultured inside a flask with filter cap containing 90 ccs RPMI 1640 medium (Gibco, USA) enriched with $10 \%$ fetal bovine serum (FBS) and $100 \mu \mathrm{l}$ antibiotics (penicillin $0.01 \mu \mathrm{g} / \mu \mathrm{l}$ and streptomycin $0.01 \mu \mathrm{g} / \mu \mathrm{l}$ ) in an incubator at $37^{\circ} \mathrm{C}$ and carbon dioxide $5 \%$. Then, the cells were passaged, separated, according to the desired seeding density calculations, and added to $3 \mathrm{~cm}$ and/or 6-well culture plates after counting.

2.2. MTT Assay. MTT is one of the water-soluble yellow tetrazolium salts, reduced by dehydrogenases in cell-activated mitochondria, and then deposits as insoluble formazan crystals in living cells. These crystals are purple, and their purple color value is proportional to cell activity and the number of living cells. Briefly, $100 \mu \mathrm{l} / \mathrm{ml}$ of medium containing cells at a density of $5 \times 10^{4}$ cells $/ \mathrm{ml}$ was seeded in each well of a flatbottom 96-well plate. Cells were permitted to adhere to the plate for $24 \mathrm{~h}\left(5 \% \mathrm{CO}_{2}\right.$ and $\left.37^{\circ} \mathrm{C}\right)$. Then, $100 \mu \mathrm{l} \mathrm{RPMI} 1640$ medium containing different concentrations of $(0,50,100$, and $150 \mu \mathrm{g} / \mathrm{ml}$ ) ZEO was incubated for $24 \mathrm{~h}$. After the above time, $20 \mu \mathrm{l}$ MTT with a concentration of $5 \mathrm{~g} / \mathrm{l}$ was added to each well and placed in the incubator at $37^{\circ} \mathrm{C}$ for 3 hours. DMSO $(100 \mu \mathrm{l} / \mathrm{ml})$ was used as the positive control, and wells were left with no cells for the negative control. Finally, after 15 minutes of incubation at room temperature, the optical absorption of the plate was measured by a spectrophotometer at $570 \mathrm{~nm}$. To obtain better results and ensure the accuracy of the obtained results, each experiment was repeated five times. The percentage of the viable cells was calculated using the following formula: $100 \times$ mean treatment absorbance/mean control absorbance; likewise, calculate percentage cytotoxicity with the following equation, using corrected absorbance: $\%$ cytotoxicity $=[100 \times($ control - sample $)]$.

2.3. Cell Culture and Grouping. After initial culture and counting, $3 \times 10^{5}$ HT-29 cells/ml were transferred to 6 -well plates and divided into two groups including group 1, HT29 cells, according to the results of MTT, with $50 \mu \mathrm{g} / \mathrm{ml}$ ZEO, and group 2, only HT-29 cells as the control group. After 24 and 48 hours of culture, mRNA and protein level expressions are evaluated by RT-PCR and western blot, respectively.

2.4. Primer Design and Quality Analysis by Agarose Gel. In this study, after obtaining exon sequences from NCBI (National Center for Biotechnology Information) and Ensembl, investigated primers were designed on two exons or as forward or reverse on the junction of two exons by Beacon Designer. Then, using Beacon, Oligo, and NCBI, PrimerBLAST was performed and primers were investigated for the position and extra bands. Then, after ordering and purchasing primers, they were diluted and used according to the manufacturer's protocol (Table 1).

Total RNA extraction was performed using Dena Zist Asia (S-1010-1), Iran. After analyzing nanodrop and agarose gel, it was converted to cDNA by Yekta Tajhiz Azma (YTA (Cost No. YT4500, Iran)) kit. Then, for denaturation, according to the binding temperature, cDNA strands were heated at $95^{\circ} \mathrm{C}$ for 10 minutes; then, a 40 -cycle period consisting of $95^{\circ} \mathrm{C}$ in 10 seconds, $60^{\circ} \mathrm{C}$ in 20 seconds, and $72^{\circ} \mathrm{C}$ in 20 seconds was used for PCR, and the quality analysis 
TABLE 1: List of different RT-qPCR primers used in the study.

\begin{tabular}{|c|c|c|c|}
\hline Gene (ENST) & Sequence $\left(5^{\prime}-3^{\prime}\right)$ & $T_{\mathrm{m}}\left({ }^{\circ} \mathrm{C}\right)$ & Length (bp) \\
\hline \multirow{2}{*}{ Caspase 3 (ENST00000393585.6) } & F: ATGGGAGCAAGTCAGTGGAC & \multirow{2}{*}{60} & \multirow{2}{*}{84} \\
\hline & R: CGTACCAGAGCGAGATGACA & & \\
\hline \multirow{2}{*}{ Caspase 9 (ENST00000469637.1) } & F: GGCGGAGCTCATGATGTCTGTG & \multirow{2}{*}{61} & \multirow{2}{*}{156} \\
\hline & R: TTCCGGTGTGCCATCTCCATCA & & \\
\hline \multirow{2}{*}{ Caspase 8 (ENST00000391871.4) } & F: GGATGGCCACTGTGAATAACTG & \multirow{2}{*}{60} & \multirow{2}{*}{101} \\
\hline & R: TCGAGGACATCGCTCTCTCA & & \\
\hline \multirow{2}{*}{ Bcl-2 (ENSG00000126453) } & F: GAGCGTCAACAGGGAGA & \multirow{2}{*}{60} & \multirow{2}{*}{164} \\
\hline & R: GCCAGGAGAAATCAAACA & & \\
\hline \multirow{2}{*}{ Bax (ENSG00000087088) } & F: ACTAAAGTGCCCGAGCTGA & \multirow{2}{*}{60} & \multirow{2}{*}{161} \\
\hline & R: ACTCCAGCCACAAAGATGGT & & \\
\hline \multirow{2}{*}{$\beta$-Actin (ENST00000515712.1) } & F: CTAССТТСААСТССАТСА & \multirow{2}{*}{60} & \multirow{2}{*}{165} \\
\hline & R: GAGCAATGATCTTGATCTTC & & \\
\hline
\end{tabular}

of primer-based PCR products was investigated primers in $2 \%$ agarose gel.

2.5. Flow Cytometry. To check apoptosis in the HT-29 colon cancer cells treated by the extract of Ziziphora tenuior L., the ZEO-treated and untreated groups of HT-29 cells were assessed by flow cytometry (BD FACSAria III) using annexin $\mathrm{V}$ and PI according to the appropriate instruction. The HT29 cells were treated with ZEO $(50 \mu \mathrm{g} / \mathrm{ml})$ and $0 \mu \mathrm{g}$ of $\mathrm{ZEO} / \mathrm{ml}$ (as untreated/control group cells) for 24 and 48 hours. Finally, the percentage of various stages of apoptotic HT-29 cells was reported.

2.6. $R T-q P C R$ and Analysis. All biological samples were placed in Rotor-Gene Q 2.3.5 RT-PCR, and $95^{\circ} \mathrm{C}$ cDNA denaturation temperature was performed for 10 minutes; then, a 40 -cycle period including $95^{\circ} \mathrm{C}$ in 10 seconds, $60^{\circ} \mathrm{C}$ in 20 seconds, and $72^{\circ} \mathrm{C}$ in 20 seconds was used for Bax, $\mathrm{Bcl}-2$, caspase 3, and caspase 9 and reading. In this experiment, Yekta Tajhiz Azma (YTZ (Cost No. YT2551, Iran)) Master Mix and SYBR Green kits were used. At first, crew standard was performed for normalization of cDNA. Then, the melting curve and CT were analyzed in each sample.

The initial analysis was performed by the GeneX v6.7, and the results were calculated in delta, delta CT, and log-2. Then, statistical analysis was performed using GraphPad Prism 8.

2.7. Western Blotting. To determine protein expression, western blot analysis was performed. Briefly, after $24 \mathrm{~h}$ of treatment with ZEO, the HT-29 cells were lysed with $70 \mu \mathrm{l}$ of PhosphoSafe ${ }^{\mathrm{TM}}$; then, protein concentration $(20 \mu \mathrm{g})$ was calculated by BCA protein analysis. Electrophoresis was performed using Nu-PAGE 10\% SDS-PAGE Bis-Tris gel in SDS-PAGE buffer. Polyvinylidene fluoride membrane (PVDF) was used for transfer. Next, membrane was blocked with bovine serum albumin (3\%). Afterwards, membranes were washed with Tris-buffered saline containing Tween 20 (TBST) and incubated overnight with primary antibody (procaspase-3 (catalog no. sc-7148; anti-rabbit), procaspase8 (catalog no. sc-7890; anti-rabbit), procaspase-9 (catalog no. sc-7885; anti-rabbit), Bcl-2 (catalog no. sc-492; anti-rabbit), BAX (catalog no. sc-493; anti-rabbit), and $\beta$-actin (cata$\log$ no. sc-47,778; anti-mouse)) diluted $1: 1000$. After that, membrane was washed three times with TBST and secondary antibody $(1: 1000)$ was added to be incubated for $1 \mathrm{~h}$ and washed with TBST. Then, band intensities were detected using a chemiluminescent substrate SuperSignal Femto kit and band densities were analyzed using Image J 1.52a program (Bethesda, Maryland, USA) [16].

2.8. Statistical Analyses. All the experiments were performed in duplicate, being the results expressed as mean \pm SEM of three independent experiments. The collected data were analyzed using $t$-test. All analyses were carried out using GraphPad Prism 8.

\section{Results}

The main compounds of Ziziphora essential oil measured by GC/MS are shown in Table 2. Figure 1 shows the Ziziphora essential oil chromatogram. 42 chemical compounds were identified. Among these, 7 compounds make up the most ZEO chemicals, given in order as follows: pulegone (26.65\%), alpha-terpinyl acetate $(9.53 \%)$, geraniol $(7.11 \%)$, menthone (5.74\%), thymol (5.51\%), alpha terpineol (3.24\%), and menthol (1.05\%) were present in respective decreasing order (Figure 1).

3.1. MTT Assay Revealed Proapoptotic Properties of ZEO on Epithelial Cancer Cells. This assay was performed to identify the concentration of $\mathrm{IC}_{50}$. The highest death was obtained in the concentration of $200 \mu \mathrm{g} / \mathrm{ml}$ at 24 hours after treatment (Figure 2). Then, according to the MTT results, the concentration of $50 \mu \mathrm{g} / \mathrm{ml}$ of ZEO was used to analyze its effect on the expression of apoptosis-associated genes. Indeed, according to the optical density-based MTT assay of ZEO un/treated HT-29 cells, the ZEO behaved in a dosedependent manner in these cancerous cells.

3.2. Flow Cytometry Results Confirmed ZEO's Proapoptotic Activity on Epithelial Cancer Cells. Flow cytometry on HT29 cells was performed to pinpoint how ZEO affected cell 
TABLe 2: Composition of Ziziphora tenuior essential oil from Iran.

\begin{tabular}{|c|c|c|c|c|c|c|c|}
\hline & Components & ${ }^{*} \mathrm{RI}$ & Chemical formula & ${ }^{* *} \mathrm{RT}$ & ${ }^{* * *}$ LRI & Identification & $\%$ \\
\hline 1 & Pulegone & 1214 & $\mathrm{C}_{10} \mathrm{H}_{16} \mathrm{O}$ & 18.11 & 1570 & RI, MS & 26.651 \\
\hline 2 & $\alpha$-Terpinyl & 960 & $\mathrm{C}_{12} \mathrm{H}_{20} \mathrm{O}_{2}$ & 14.45 & 970 & RI, MS & 9.533 \\
\hline 3 & Geraniol & 1211 & $\mathrm{C}_{10} \mathrm{H}_{18} \mathrm{O}$ & 14.80 & 1274 & RI, MS & 7.114 \\
\hline 4 & Menthone & 985 & $\mathrm{C}_{10} \mathrm{H}_{18} \mathrm{O}$ & 13.91 & 990 & RI, MS & 5.744 \\
\hline 5 & Thymol & 2010 & $\mathrm{C}_{10} \mathrm{H}_{14} \mathrm{O}$ & 21.50 & 2020 & RI, MS & 5.512 \\
\hline 6 & $\alpha$-Terpineol & 1011 & $\mathrm{C}_{10} \mathrm{H}_{18} \mathrm{O}$ & 15.56 & 1097 & RI, MS & 3.247 \\
\hline 7 & Menthol & 2035 & $\mathrm{C}_{10} \mathrm{H}_{20} \mathrm{O}$ & 22.35 & 2065 & RI, MS & 1.051 \\
\hline 8 & Octanol & 983 & $\mathrm{C}_{8} \mathrm{H}_{18} \mathrm{O}$ & 11.43 & 989 & RI, MS & 0.965 \\
\hline 9 & $\alpha$-Pinene & 930 & $\mathrm{C}_{10} \mathrm{H}_{16}$ & 6.76 & 939 & RI, MS & 0.865 \\
\hline 10 & Camphene & 943 & $\mathrm{C}_{10} \mathrm{H}_{16}$ & 7.29 & 950 & RI, MS & 0.861 \\
\hline 11 & Sabinene & 964 & $\mathrm{C}_{10} \mathrm{H}_{16}$ & 29.96 & 972 & RI, MS & 0.88 \\
\hline 12 & $\beta$-Pinene & 979 & $\mathrm{C}_{10} \mathrm{H}_{16}$ & 8.20 & 976 & RI, MS & 0.758 \\
\hline 13 & Myrcene & 871 & $\mathrm{C}_{10} \mathrm{H}_{16}$ & 14.62 & 991 & RI, MS, ${ }^{1} \mathrm{H}-\mathrm{NMR}$ & 0.965 \\
\hline 14 & Limonene & 1010 & $\mathrm{C}_{10} \mathrm{H}_{16}$ & 10.07 & 1020 & RI, MS, ${ }^{13} \mathrm{C}$ NMR & 1.035 \\
\hline 15 & $\alpha$-Terpinene & 995 & $\mathrm{C}_{10} \mathrm{H}_{16}$ & 11.86 & 1018 & RI, MS & 0.51 \\
\hline 16 & Eucalyptol & 1020 & $\mathrm{C}_{10} \mathrm{H}_{18} \mathrm{O}$ & 10.26 & 1069 & RI, MS & 0.125 \\
\hline 17 & $\gamma$-Terpinene & 1050 & $\mathrm{C}_{10} \mathrm{H}_{16}$ & 11.16 & 1060 & RI, MS & 0.1258 \\
\hline 18 & Linalool & 1080 & $\mathrm{C}_{10} \mathrm{H}_{18} \mathrm{O}$ & 12.53 & 1097 & RI, MS & 0.115 \\
\hline 19 & Terpinolene & 1075 & $\mathrm{C}_{10} \mathrm{H}_{16}$ & 19.29 & 1089 & RI, MS & 0.356 \\
\hline 20 & Isomenthone & 1141 & $\mathrm{C}_{10} \mathrm{H}_{18} \mathrm{O}$ & 15.47 & 1148 & RI, MS, ${ }^{13} \mathrm{C}$ NMR & 0.458 \\
\hline 21 & Isomenthol & 1102 & $\mathrm{C}_{10} \mathrm{H}_{20} \mathrm{O}$ & 15.23 & 1115 & $\mathrm{RI}, \mathrm{MS},{ }^{13} \mathrm{C} \mathrm{NMR}$ & 0.18 \\
\hline 22 & Piperitenone & 1340 & $\mathrm{C}_{10} \mathrm{H}_{16} \mathrm{O}$ & 31.14 & 1346 & RI, MS & 0.256 \\
\hline 23 & Carvacrol & 1296 & $\mathrm{C}_{10} \mathrm{H}_{14} \mathrm{O}$ & 30.57 & 1303 & RI, MS & 0.198 \\
\hline 24 & Epi alpha cadinol & 1210 & $\mathrm{C}_{15} \mathrm{H}_{26} \mathrm{O}$ & 35.41 & 1218 & RI, MS & 0.056 \\
\hline 25 & Spathulenol & 1567 & $\mathrm{C}_{15} \mathrm{H}_{24} \mathrm{O}$ & 42.10 & 1585 & $\mathrm{RI}, \mathrm{MS},{ }^{1} \mathrm{H}-\mathrm{NMR}$ & 0.145 \\
\hline 26 & Nerolidol & 1573 & $\mathrm{C}_{15} \mathrm{H}_{26} \mathrm{O}$ & 18.41 & 1582 & $\mathrm{RI}, \mathrm{MS},{ }^{1} \mathrm{H}-\mathrm{NMR}$ & 0.11 \\
\hline 27 & $\delta$-Cadinene & 1440 & $\mathrm{C}_{15} \mathrm{H}_{24}$ & 17.69 & 1446 & $\mathrm{RI}, \mathrm{MS},{ }^{1} \mathrm{H}-\mathrm{NMR}$ & 0.35 \\
\hline 28 & $\gamma$-Cadinene & 1531 & $\mathrm{C}_{15} \mathrm{H}_{24}$ & 38.60 & 1535 & RI, MS & 0.44 \\
\hline 29 & $\beta$-Bisabolene & 1507 & $\mathrm{C}_{15} \mathrm{H}_{24}$ & 8.24 & 1514 & RI, MS & 0.49 \\
\hline 30 & Germacrene-D & 1474 & $\mathrm{C}_{15} \mathrm{H}_{24}$ & 37.28 & 1481 & $\mathrm{RI}, \mathrm{MS},{ }^{1} \mathrm{H}-\mathrm{NMR}$ & 0.756 \\
\hline 31 & Eugenol & 1380 & $\mathrm{C}_{10} \mathrm{H}_{12} \mathrm{O}_{2}$ & 24.52 & 1384 & RI, MS & 0.668 \\
\hline 32 & Eucalyptol & 1030 & $\mathrm{C}_{10} \mathrm{H}_{18} \mathrm{O}$ & 10.22 & 1032 & RI, MS & 0.12 \\
\hline 33 & 2-Nonen-1-ol & 758 & $\mathrm{C}_{9} \mathrm{H}_{18} \mathrm{O}$ & 11.93 & 771 & RI, MS & 0.189 \\
\hline 34 & cis- $\beta$-Farnesene & 894 & $\mathrm{C}_{15} \mathrm{H}_{24}$ & 28.20 & 923 & RI, MS & 0.106 \\
\hline 35 & $\gamma$-Elemene & 1102 & $\mathrm{C}_{15} \mathrm{H}_{24}$ & 29.69 & 1437 & $\mathrm{RI}, \mathrm{MS},{ }^{1} \mathrm{H}-\mathrm{NMR}$ & 0.1 \\
\hline 36 & Carvone & 1223 & $\mathrm{C}_{10} \mathrm{H}_{14} \mathrm{O}$ & 31.50 & 1240 & RI, MS & 0.08 \\
\hline 37 & Cyclohexanone & 1254 & $\mathrm{C}_{6} \mathrm{H}_{10} \mathrm{O}$ & 19.41 & 1260 & RI, MS & 0.09 \\
\hline 38 & Butanoic acid & 1205 & $\mathrm{C}_{4} \mathrm{H}_{8} \mathrm{O}_{2}$ & 22.36 & 1209 & RI, MS & 0.05 \\
\hline 39 & $\beta$-Bourbonene & 1385 & $\mathrm{C}_{15} \mathrm{H}_{24}$ & 21.54 & 1392 & RI, MS & 0.1 \\
\hline 40 & Caryophyllene & 1415 & $\mathrm{C}_{15} \mathrm{H}_{24}$ & 34.61 & 1417 & RI, MS, ${ }^{1} \mathrm{H}-\mathrm{NMR}$ & 0.03 \\
\hline 41 & Humulene & 1454 & $\mathrm{C}_{15} \mathrm{H}_{24}$ & 25.86 & 1455 & RI, MS, ${ }^{1} \mathrm{H}-\mathrm{NMR}$ & 0.07 \\
\hline 42 & 4,7-Dimethoxy-5-[prop-1-en-1-yl]-2H-1,3-benzodioxole & 900 & $\mathrm{C}_{12} \mathrm{H}_{14} \mathrm{O}_{4}$ & 34.99 & 912 & RI, MS, ${ }^{1} \mathrm{H}-\mathrm{NMR}$ & 0.056 \\
\hline
\end{tabular}

${ }^{*}$ RI: retention indices calculated on apolar; ${ }^{* *} \mathrm{RT}$ : retention time $(\mathrm{min}) ;{ }^{* * *}$ LRI: retention indices of literature.

death (apoptosis or necrosis). Data analysis was performed using software following the division of a two-dimensional annexin $\mathrm{V}$ versus PI curve into four regions/quadrants (Qs) (Q1, Q2, Q3, and Q4). In this division, Q1 represents necrotic HT-29 cells with annexin $\mathrm{V}^{-}$and $\mathrm{PI}^{+}$; the Q2 region represents the late stage of apoptotic HT-29 cells with characteris- tics of annexin $\mathrm{V}^{+}$and $\mathrm{PI}^{+}$; the $\mathrm{Q} 3$ region represents healthy cells with annexin $\mathrm{V}^{-}$and $\mathrm{PI}^{-}$; and the Q4 region represents early apoptotic HT-29 cells with characteristics of annexin $\mathrm{V}^{+}$and $\mathrm{PI}^{-}$. The average of Q1, Q2, Q3, and Q4 in ZEOchallenged HT-29 cells after $48 \mathrm{~h}$ was $0.26,0.70 \%, 34.33 \%$, and $64.62 \%$, respectively (Figure 3 ). The 24 and 48 hours of 


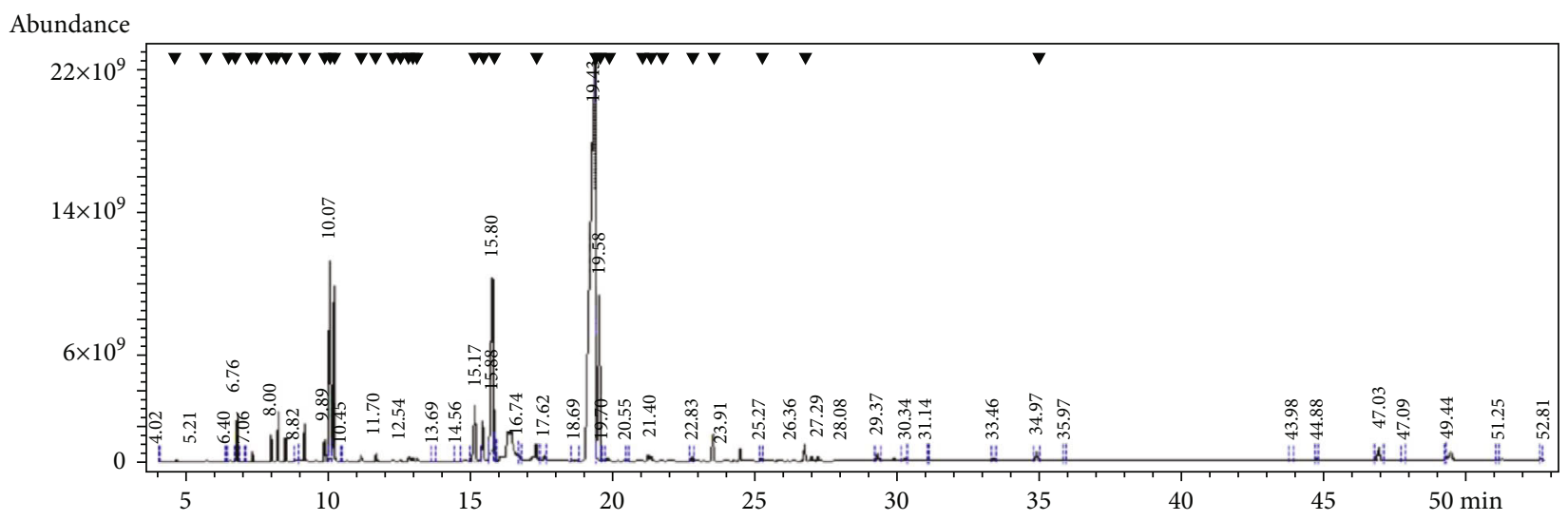

(a)

Abundance

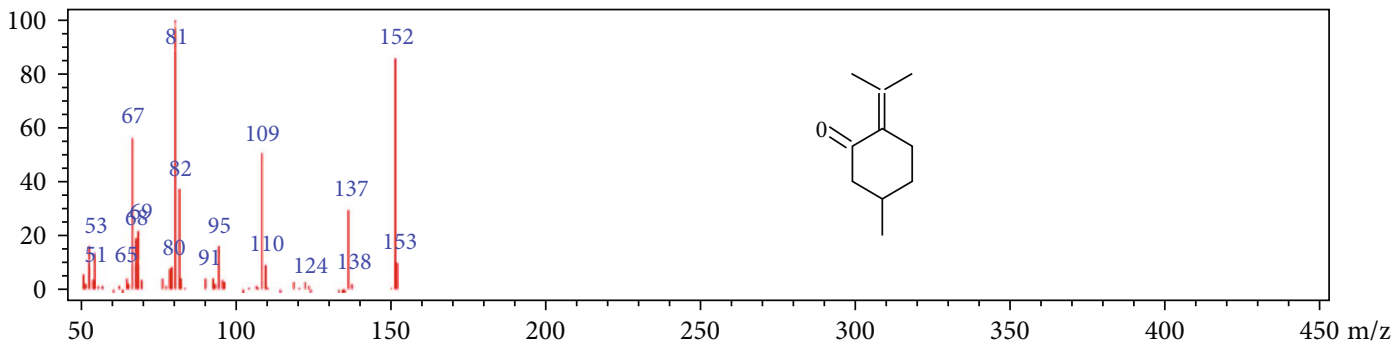

(b)

FIGURE 1: The existence of pulegone in ZEO GC/MS. (a) Chromatogram of Ziziphora essential oil (ZEO). (b) Chemical structure of pulegone in ZEO.

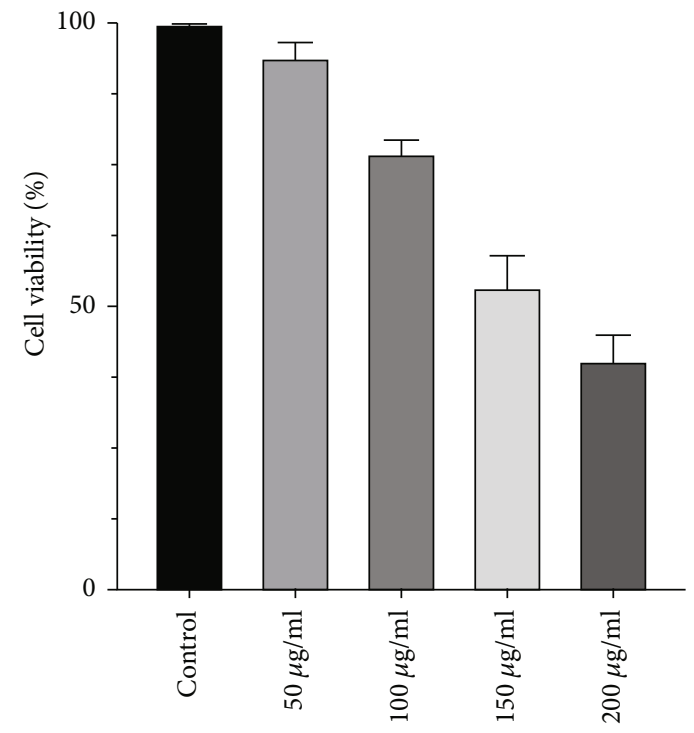

Figure 2: Percentage of the viability of treated HT-29 cells with different concentrations of Ziziphora essential oil (ZEO).

incubation of HT-29 cells with $50 \mu \mathrm{g} / \mathrm{ml}$ of ZEO caused timedependent apoptosis (Figure 3 ). The percentage of early apoptotic HT-29 cells was $12.35 \pm 1.96$ and $33.54 \pm 2.12$, respectively (Figure $3(\mathrm{~b})$ ). Microscopic results also confirmed the results so that the number of cells in the treated groups with Ziziphora tenuior L. after 24- and 48-hour incubation was lower than that of untreated (control) ones (Figure 4(a)).
Also, changes in cell morphology and apoptosis following ZEO challenge were evident.

3.3. Altering the Levels of Bax, Bcl-2, C3, and C9 Gene Expression in ZEO-Exposed Epithelial Cancer Cells. Caspase 3 and 9 expressions at the protein level in the Ziziphora tenuior L.-treated groups ( 24 and 48 hours) increased compared to those in the control group, but Bax expression did not show a significant change. The $\mathrm{Bcl}-2$ expression decreased only in the 48-hour treated group with Ziziphora tenuior L. compared to the control group $(P=0.0191)$ (Figure 4(b)).

Figure 4(c) shows the expression of the studied genes at the mRNA level; the results showed that caspase 3 and 9 expressions at the mRNA level in the treated groups with Ziziphora tenuior L. (24 and 48 hours) increased compared to those in the control group $(P<0.0001)$, but the expression level of $\mathrm{Bcl}-2$ in the treated groups decreased significantly compared to the control group $(P<0.0001)$. Bax expression only in the Ziziphora tenuior L. group treated for 48 hours decreased significantly compared to that in the control group $(P=0.0197)$. Similar results on the protein levels were finally confirmed with western blotting of the protein expression of Bax, Bcl-2, C3, and C9.

\section{Discussion}

The results of this study showed that the most abundant compound of Ziziphora essential oil is pulegone. Although 
Control

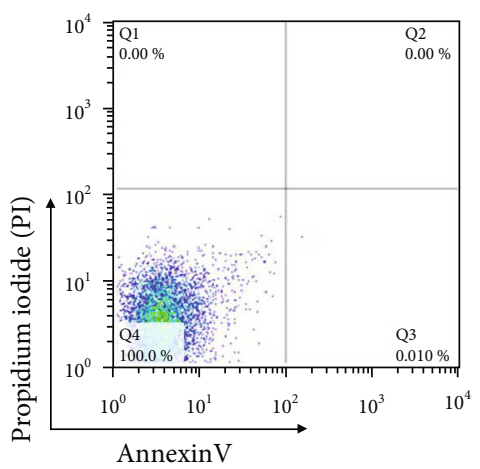

$100 \mu \mathrm{g} / \mathrm{ml}(24 \mathrm{~h})$

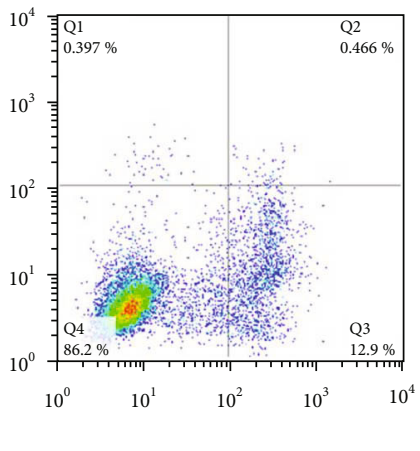

$100 \mu \mathrm{g} / \mathrm{ml}(48 \mathrm{~h})$

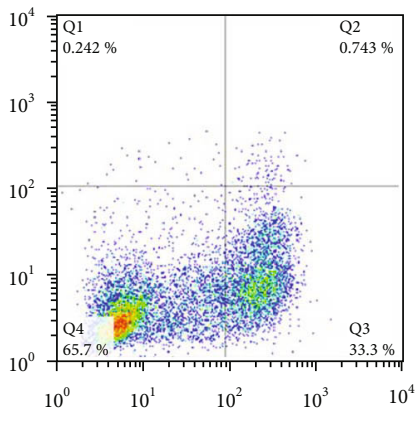

(a)

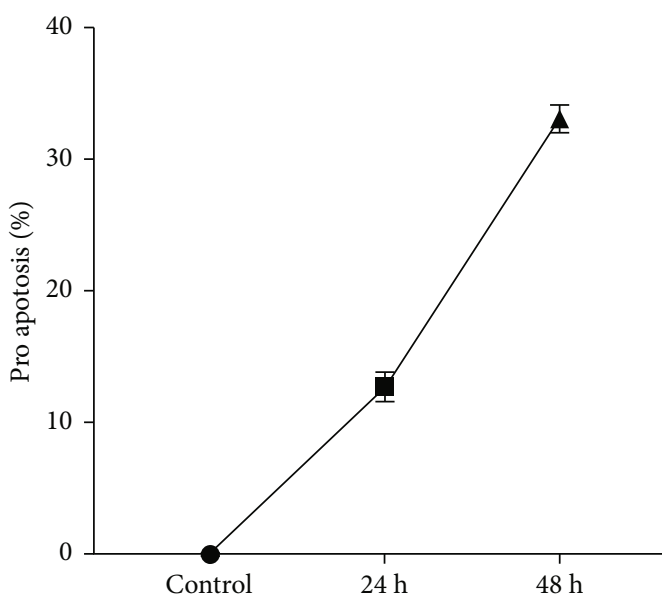

(b)

FIGURE 3: Effect of concentration of $50 \mu \mathrm{g} / \mathrm{ml}$ of Ziziphora essential oil (ZEO) on apoptosis in HT-29 cells. (a) Flow cytometry figure (annexin v/PI), Q4 healthy cells, Q3 early apoptosis, Q2 late apoptosis, and Q1 necrosis. (b) Percentage of early apoptotic cells after 24- and 48-hour incubation of HT-29 cells with ZEO.

a comparison of the chromatography results of ZEO (Figure 1 and Table 2) with the extracts of oils of other Ziziphora species shows partial similarities among them, but still some dissimilarities on its chemical composition might mainly be due to the growing conditions of the plant, water and air conditions, place of growth, altitude, etc. (20-23). Various studies have shown that pulegone is the main ingredient in various Ziziphora species (20-25); nonetheless, the percentage of pulegone in the present study is lower than that in other studies.

Also, the concentration of $50 \mu \mathrm{g} / \mathrm{ml}$ of $\mathrm{ZEO}$ reduces the number and imposes morphological changes in HT-29 cells. Additionally, the expression of caspases 3 and 9 in ZEOtreated cells with increasing ZEO showed an increase in their expressions compared to the control group. These changes can lead cells to apoptosis. Different studies have shown pulegone can stimulate apoptosis [17, 18]. Pulegone causes apoptosis by reducing NF- $\kappa \mathrm{B}$ activity [19]. Also, the investigated $\mathrm{ZEO}$ contained menthol and menthone that can cause apoptosis [20]. In 2013, the toxic effect of four medicinal plants including Ziziphora clinopodioides Lam. on epithelial cells of colorectal cancer was investigated and the results showed that Ziziphora clinopodioides Lam. has anti- tumor properties [21]. Another study in 2016 examined the chemical compounds and anticancer effects of aerial parts of Ziziphora clinopodioides Lam. The toxic effect of this plant on cell lines of colorectal cancer (HT-29), breast cancer (T-47D), leukemia (K-562), and mouse embryonic fibroblasts was investigated. The results indicated an extraordinary inhibitory and toxic effect of Ziziphora clinopodioides Lam. compounds on these cancerous cell lines that are consistent with the present study.

In this study, the main extracted compounds were pulegone (24\%), menthol (14\%), and menthone (9\%) [22]. Other studies showed a tumor suppressor mechanism so that P53 acts as a transcription factor for a set of proapoptotic proteins from the BCL family (Puma, Bid, Noxa, and Bax). It eventually induces mitochondrial permeability and releases cytochrome $c$. Cytochrome $c$ is essential for apaf1 activation; this protein is vital in activating the caspase activation pathway. P53 also induces ASC (apoptosis-associated speck-like protein), which plays a role in the positioning of Bax protein in the mitochondria and induction of mitochondrial membrane permeability for cytochrome $c$ release [23-25]. In Figure 5, the mechanism of apoptosis by Ziziphora pulegone and menthol is presented. Various studies have shown that 

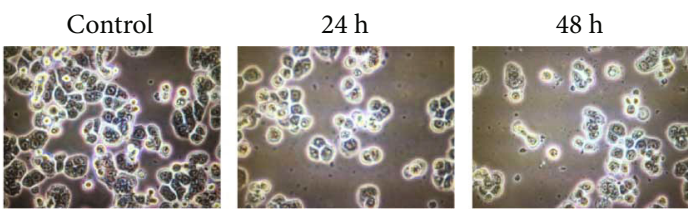

(a)
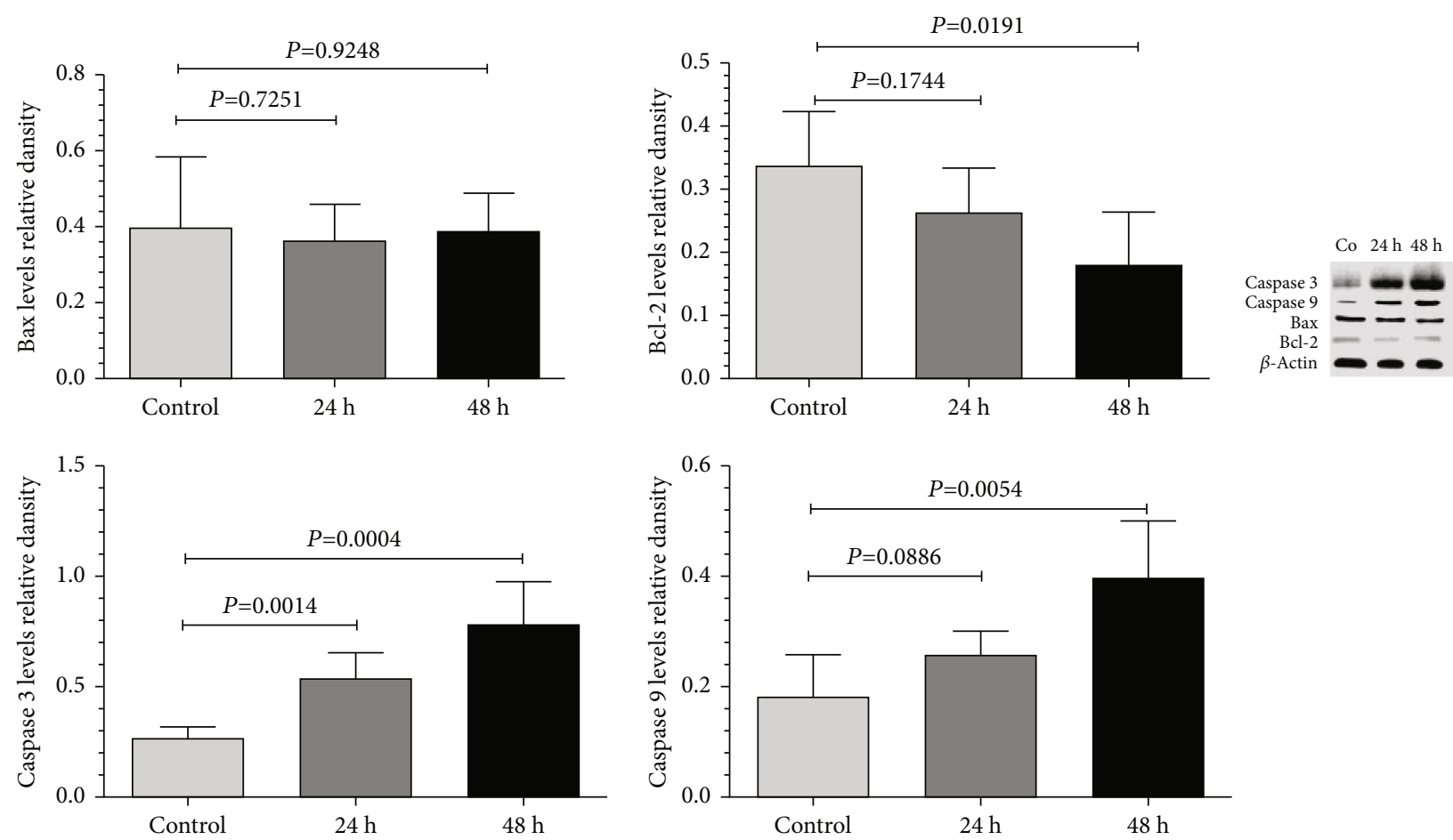

(b)
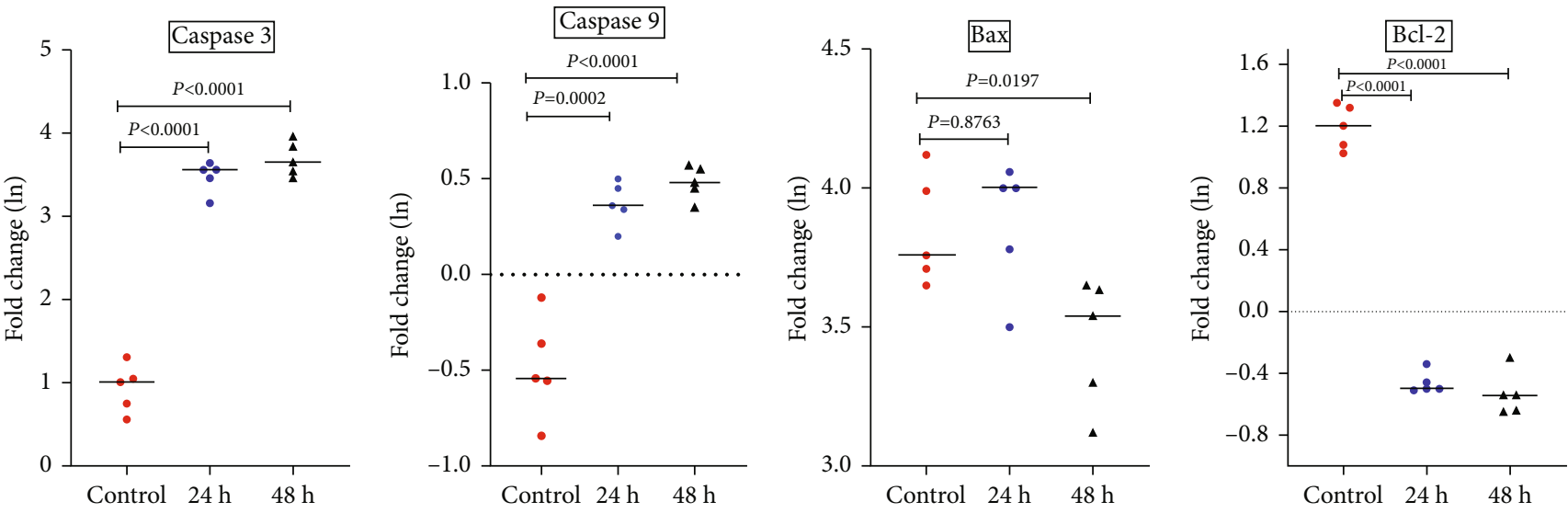

(c)

Figure 4: Ziziphora essential oil- (ZEO-) induced apoptosis includes an increase in caspase 3 and 9 and a decrease in Bcl-2 and Bax expressions in HT-29 cells. (a) Light microscopic pictures ( $\times 100$ magnification) with arrows represent the morphological changes caused by apoptosis in the examined HT-29 cells. (b) Bax, Bcl-2, C3, and C9 expression results obtained by western blot in HT-29 cells. (c) mRNA, Bax, Bcl-2, C3, and C9 results obtained by RT-PCR.

pulegone reduces NF- $\kappa$ B followed by apoptosis [26-28]. Roy et al. showed that pulegone reduces inflammation caused by LPS by reducing the effects of NF- $\kappa$ B [29]. Souldouzi et al. also showed that pulegone causes apoptosis in mouse ovarian follicular cells [28]. Menthol is another important compound of ZEO. Various studies have shown that menthol activates caspases 3 and 7 through caspase 10 affecting HSP90, followed by apoptosis [30-32].

The results of the present study showed that ZEO increases the levels of caspases 3 and 9 at mRNA and protein 


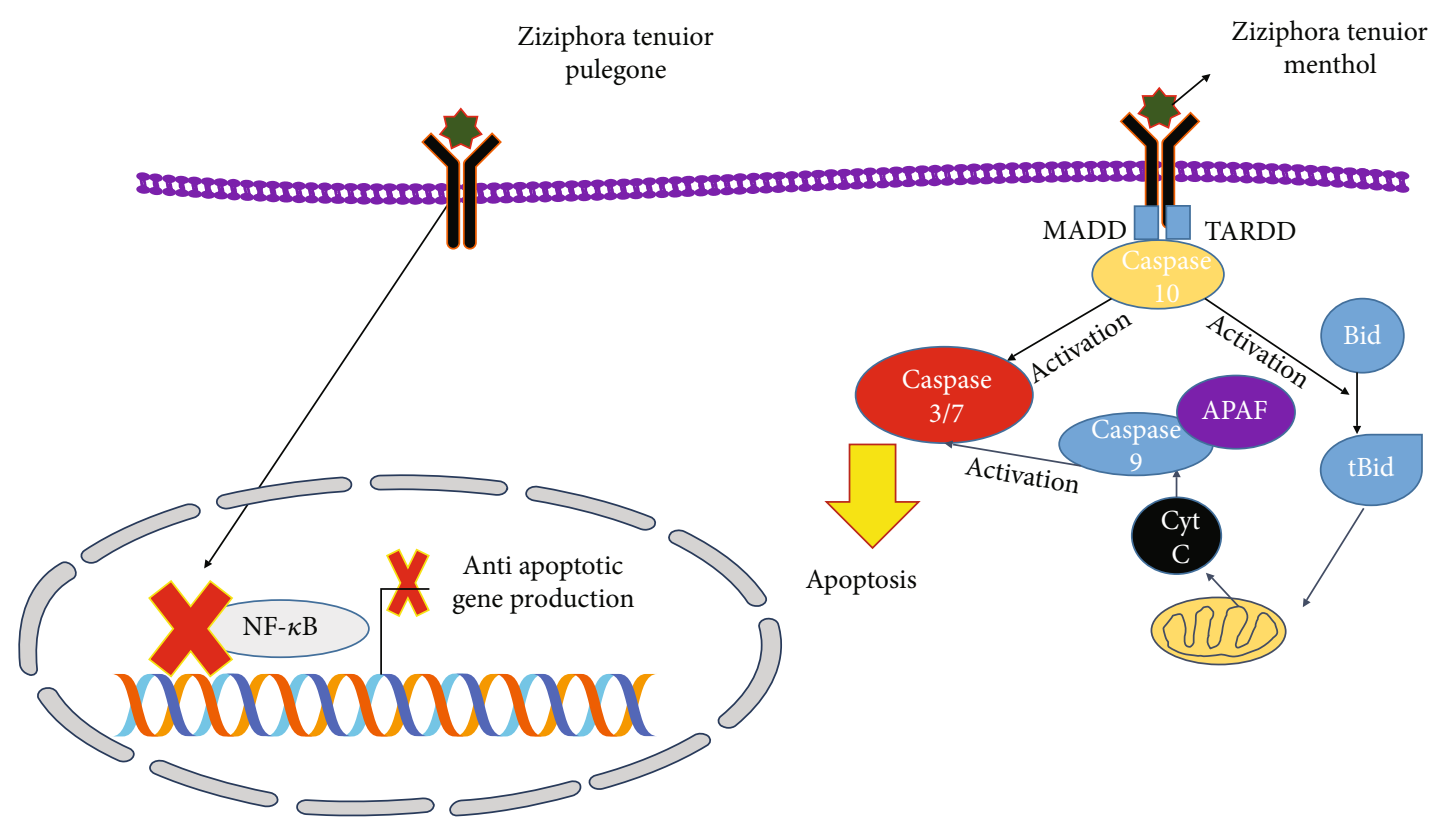

Figure 5: Schematic view of the effect of Ziziphora essential oil (ZEO) on apoptosis through pulegone and menthol. On the other hand, menthol activates caspase 10, followed by activation of the Bid pathway, and caspases 3 and 7 cause apoptosis.

levels in HT-29 cells and decreases the amount of Bcl-2. It seems highly likely that the compounds such as menthol and polygon could cause apoptosis in HT-29 cells through the NF- $\kappa \mathrm{B}$ pathway as well as activate caspases through the TRPM8 channel [23-25, 33]. Chemical analyses of ZEO showed that among the 42 various compounds in analyzed ZEO, pulegone (26.65\%), alpha-terpinyl acetate (9.53\%), and geraniol $(7.11 \%)$ were the main compounds, which might have broad effects on cancer cells.

Indeed, here we used only cell lines and only a single concentration of ZEO, which is inadequate to draw a strong conclusion; as such, examining the effects of various concentrations of ZEO on a particular normal cell line is warranted. Nonetheless, the results showed that ZEO due to having anticancer compounds such as menthol and pulegone can increase the expression of C3 and C9 and decrease Bcl2 , causing apoptosis in HT-29 cells in vitro. These can be courageous points to the application of ZEO as a medicinal plant of choice for the treatment of CRC.

\section{Data Availability}

The datasets generated during and/or analyzed during the current study are available from the corresponding author on reasonable request.

\section{Ethical Approval}

This study has been approved by the Ethics Committee of the Ferdowsi University of Mashhad, Mashhad, Iran.

\section{Conflicts of Interest}

The authors declare that they have no conflict of interest.

\section{Authors' Contributions}

Mohammadreza Azimi, Jalil Mehrzad, and Ali Ghorbani Ranjbary performed the experiments, conceived and designed the study, and wrote, analyzed, funded, and critically revised the manuscript. Armita Ahmadi and Elnaz Ahmadi also actively helped in the experiments and participated in study design, study implementation, and manuscript revision. All authors read and approved the final manuscript. The corresponding author is Ali Ghorbani Ranjbary.

\section{References}

[1] A. G. Ranjbary, J. Mehrzad, H. Dehghani, A. Abdollahi, and S. Hosseinkhani, "Variation in blood and colorectal epithelia's key trace elements along with expression of mismatch repair proteins from localized and metastatic colorectal cancer patients," Biological Trace Element Research, vol. 194, no. 1, pp. 66-75, 2020.

[2] B. C. Bade and C. S. dela Cruz, "Lung cancer 2020: epidemiology, etiology, and prevention," Clinics in Chest Medicine, vol. 41, no. 1, pp. 1-24, 2020.

[3] B. Pardini, A. Corrado, E. Paolicchi et al., "DNA repair and cancer in colon and rectum: novel players in genetic susceptibility," International Journal of Cancer, vol. 146, no. 2, pp. 363-372, 2020.

[4] S. Soltanian, H. Riahirad, A. Pabarja, E. Jafari, and B. K. Khandani, "Effect of cinnamic acid and FOLFOX in diminishing side population and downregulating cancer stem cell markers in colon cancer cell line HT-29," DARU Journal of Pharmaceutical Sciences, vol. 26, no. 1, pp. 19-29, 2018.

[5] K. Abdi, A. Khalaj, S. N. Ostad, and M. R. Khoshayand, "Cytotoxicity and radiosensitising activity of synthesized 
dinitrophenyl derivatives of 5-fluorouracil," DARU Journal of Pharmaceutical Sciences, vol. 20, no. 1, p. 3, 2012.

[6] P. Rawla, T. Sunkara, and A. Barsouk, "Epidemiology of colorectal cancer: incidence, mortality, survival, and risk factors," Przeglad Gastroenterologiczny, vol. 14, no. 2, pp. 89-103, 2019.

[7] A. Akbari, S. Amanpour, S. Muhammadnejad et al., "Evaluation of antitumor activity of a TGF-beta receptor I inhibitor (SD-208) on human colon adenocarcinoma," DARU Journal of Pharmaceutical Sciences, vol. 22, no. 1, p. 47, 2014.

[8] D. Hirsch, S. Seyfried, T. Staib et al., "Newly established gastrointestinal cancer cell lines retain the genomic and immunophenotypic landscape of their parental cancers," Scientific Reports, vol. 10, no. 1, p. 17895, 2020.

[9] M. Ahmed, K. Chaudhari, R. Babaei-Jadidi, L. V. Dekker, and A. Shams Nateri, "Concise review: emerging drugs targeting epithelial cancer stem-like cells," Stem Cells, vol. 35, no. 4, pp. 839-850, 2017.

[10] A. Ghorbani Ranjbary, S. Asmarian, F. Ghorat, and N. Jaberi, "Effect of hydroalcoholic leaves extract of Ziziphora tenuior L. on pain in male rats," Journal of Basic and Clinical Pathophysiology, vol. 4, no. 2, pp. 17-22, 2016.

[11] A. Ghorbani, S. M. Alavian, and M. Roshani, "Analgesic effect of Ziziphora tenuior essential oil and lubricant gel in patients referring for colonoscopy: a randomized double-blind clinical trial," Govaresh, vol. 25, no. 1, pp. 51-55, 2020.

[12] A. Ghorbani Ranjbary, M. Yaryar, F. Joybar, and N. Ghorbani, "The analgesic effects of Ziziphora tenuior in adult male mice," Yafte, vol. 16, no. 4, pp. 62-69, 2015.

[13] K. Šmejkal, M. Malaník, K. Zhaparkulova et al., "Kazakh Ziziphora species as sources of bioactive substances," Molecules, vol. 21, no. 7, p. 826, 2016.

[14] M. Shahnazi, H. Aghaei, R. Hajiaghaee et al., "Hydatid cyst killing mechanism of Ziziphora tenuior by inducing apoptosis via mitochondrial intrinsic pathway," Research Journal of Pharmacognosy, vol. 7, no. 1, pp. 17-22, 2020.

[15] F. Yousefbeyk, J. Tabaside, S. N. Ostad, M. H. Salehi Sourmaghi, and G. R. Amin, "Investigation of chemical composition and cytotoxic activity of aerial parts of Ziziphora clinopodioides Lam," Research Journal of Pharmacognosy, vol. 3, no. 2, pp. 47-51, 2016.

[16] A. Azadmehr, R. latifi, S. Mosalla, R. Hajiaghaee, and M. Shahnazi, "Immunomodulatory effects of Ziziphora tenuior L. extract on the dendritic cells," DARU Journal of Pharmaceutical Sciences, vol. 22, no. 1, p. 63, 2014.

[17] A. Lis, W. Kowalska, M. Sienkiewicz, and P. Banaszczak, "Chemical composition and antibacterial activity of the essential oil of Phellodendron lavallei," Natural Product Communications, vol. 12, no. 1, 2017.

[18] F. Tomi and J. Casanova, "13C NMR as a tool for identification of individual components of essential oils from Labiatae - A Review," Acta Horticulturae, vol. 723, no. 723, pp. 185-192, 2006.

[19] A. G. Pirbalouti, A. Amirkhosravi, F. Bordbar, and B. Hamedi, "Diversity in the chemical composition of essential oils of Ziziphora tenuior as a potential source of pulegone," Chemija, vol. 24, no. 3, pp. 234-239, 2013.

[20] H. Maral, H. Taghikhani, K. A. Alpaslan, and S. Kirici, “The effect of different levels of altitutes on composition and content of essential oils of Ziziphora clinopodioides in southern of Turkey," Uluslararası Tarım ve Yaban Hayatı Bilimleri Dergisi, vol. 1, no. 1, pp. 1-6, 2015.
[21] H. Batooli, M. Akhbari, and S. M. Hosseinizadeh, "Effect of different distillation methods on quantity and quality of essential oil of two Ziziphora L. species," Journal of Medicinal Herbs, vol. 3, no. 3, pp. 135-146, 2012.

[22] M. S. Abu-Darwish, C. Cabral, M. J. Gonçalves et al., “Ziziphora tenuior L. essential oil from Dana Biosphere Reserve (Southern Jordan); Chemical characterization and assessment of biological activities," Journal of Ethnopharmacology, vol. 194, pp. 963-970, 2016.

[23] I. Miller, M. Min, C. Yang et al., "Ki67 is a graded rather than a binary marker of proliferation versus quiescence," Cell Reports, vol. 24, no. 5, pp. 1105-1112.e5, 2018.

[24] B. J. Aubrey, G. L. Kelly, A. Janic, M. J. Herold, and A. Strasser, "How does p53 induce apoptosis and how does this relate to p53-mediated tumour suppression?," Cell Death \& Differentiation, vol. 25, no. 1, pp. 104-113, 2018.

[25] T. Ozaki and A. Nakagawara, "Role of p 53 in cell death and human cancers," Cancers, vol. 3, no. 1, pp. 994-1013, 2011.

[26] I. Telci, I. Demirtas, E. Bayram, O. Arabaci, and O. Kacar, "Environmental variation on aroma components of pulegone/piperitone rich spearmint (Mentha spicata L.)," Industrial Crops and Products, vol. 32, no. 3, pp. 588-592, 2010.

[27] M. Franquesa, M. J. Hoogduijn, E. Ripoll et al., "Update on controls for isolation and quantification methodology of extracellular vesicles derived from adipose tissue mesenchymal stem cells," Frontiers in Immunology, vol. 5, p. 525, 2014.

[28] R. Souldouzi, M. Razi, A. S. Jalali, G. Jalilzadeh-Amin, and S. Amani, "Effect of (R)-(+) pulegone on ovarian tissue; correlation with expression of aromatase Cyp 19 and ovarian selected genes in mice," Cell Journal (Yakhteh), vol. 20, no. 2, p. 231, 2018.

[29] A. Roy, H. J. Park, Q. A. Abdul, H. A. Jung, and J. S. Choi, "Pulegone exhibits anti-inflammatory activities through the regulation of NF- $\kappa \mathrm{B}$ and Nrf- 2 signaling pathways in LPSstimulated RAW 264.7 cells," Natural Product Sciences, vol. 24, no. 1, pp. 28-35, 2018.

[30] V. R. Baichwal and P. A. Baeuerle, "Apoptosis: activate NF- $\kappa$ B or die?," Current Biology, vol. 7, no. 2, pp. R94-R96, 1997.

[31] U. Faridi, S. S. Dhawan, S. Pal et al., "Repurposing L-menthol for systems medicine and cancer therapeutics? L-Menthol induces apoptosis through caspase 10 and by suppressing HSP90," Omics: a Journal of Integrative Biology, vol. 20, no. 1, pp. 53-64, 2016.

[32] E. S. al-Sheddi, N. A. al-Zaid, M. M. al-Oqail, S. M. al-Massarani, A. A. el-Gamal, and N. N. Farshori, "Evaluation of cytotoxicity, cell cycle arrest and apoptosis induced by Anethum graveolens $L$. essential oil in human hepatocellular carcinoma cell line," Saudi Pharmaceutical Journal, vol. 27, no. 7, pp. 1053-1060, 2019.

[33] T. Ghazanfari, R. Yaraee, J. Shams, B. Rahmati, T. Radjabian, and H. Hakimzadeh, "Cytotoxic effect of four herbal medicines on gastric cancer (AGS) cell line," Food and Agricultural Immunology, vol. 24, no. 1, pp. 1-7, 2013. 